DOI: https://doi.org/10.47405/mjssh.v6i9.1009

\begin{tabular}{|c|c|}
\hline 4 & Malaysian Journal of Social Sciences and Humanities (MJSSH) \\
\hline $\begin{array}{l}\text { Malaysian Juoural of } \\
\text { Social ccciecces and }\end{array}$ & Volume 6, Issue 9, September 2021 \\
\hline (MJ-sSH) & e-ISSN : 2504-8562 \\
\hline & $\begin{array}{l}\text { Journal home page: } \\
\text { www.msocialsciences.com }\end{array}$ \\
\hline
\end{tabular}

\title{
Analisis Hubungan Semantik Pada Perkataan Qurūnan ( قُرُونًا ) dalam Al-Quran
}

\author{
Asma Abdul Rahman', Sarah Husna M Rasid' \\ ${ }^{1}$ Fakulti Pengajian Bahasa Utama (FPBU), Universiti Sains Islam Malaysia (USIM) \\ Correspondence: Asma Abdul Rahman (asma@usim.edu.my)
}

\begin{abstract}
Abstrak
Kajian ini dilakukan bertujuan untuk menganalisis makna Semantik perkataan Qurūnan dalam AlQuran. Apakah maksud Qurūnan dalam Al-Quran? Perkataan Qurūnan merupakan istilah generasi atau umat-umat yang lain dalam Al-Quran. Perkataan Qurūnan ( قُرُونًا ) sahaja direkodkan sebanyak tiga kali dalam Al-Quran iaitu dalam Surah Al-Mukminun, Al-Furqan dan Al-Qisas. Dalam kajian ini, penulis mengumpulkan juga semua ayat yang mengandungi perkataan Qurūnan dari kata dasar yang sama iaitu قَ $َ$ sama ada berbentuk tunggal atau dalam bentuk jamak. Dari pelbagai makna perkataan, kemudian penulis akan menganalisis makna perkataan Qurūnan dalam setiap ayat dan kemudian makna Qurūnan itu sendiri diterangkan. Kajian ini bersifat kualitatif dengan menggunakan kaedah analisis teks dalam Al-Quran dengan dibantu oleh korpus Al-Quran, Al-Mu'jam Al-Mufahras Li Alfaz Al-Quran dan Kamus Mu'jam Al-Waseet Edisi Keempat. Hasil carian dalam Korpus Al-Quran menunjukkan bahawa sebanyak 36 ayat berkaitan قَ قَ dikenal pasti manakala hasil carian dalam Mu'jam Al-Mufahras Li Alfaz Al-Quran pula ada sebanyak 40 ayat dari kata kunci قَ $َ$ dikumpulkan. Adapun dalam kamus Mu'jam Al-Waseet Edisi Keempat pula menafsirkan 20 makna perkataan yang berbeza. Dapatan ini merumuskan bahawa hubungan semantik sesuai digunakan sebagai kaedah pengumpulan data tekstual secara sistematik bagi mengelakkan keciciran data dan memastikan data yang dikumpul merangkumi bidang kajian.
\end{abstract}

Kata kunci: Al-Quran, Qurūnan, Semantik, Analisis Teks

\section{Analysis of Semantic Relationships in Qur'an Words Qurūnan (قُرُونًا ) in The Qur'an}

\begin{abstract}
This study was conducted to analyze the semantic meaning of the word Qurünan in the Quran. What is the meaning of qurūnan in al-quran? The word Qurūnan is a term for other generations or peoples in the Qur'an. The word Qurūnan ( قُرُْونَا) alone is recorded three times in the Al-Quran, namely in Surah Al-Mukminun, Al-Furqan and Al-Qisas. In this study, the author also collects all the verses that contain

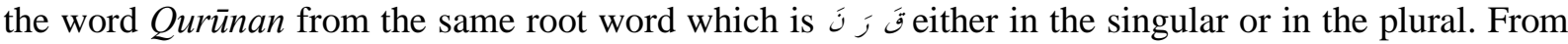
the various meanings of the word, then the author will analyze the meaning of the word Qurünan in Each verse and then the meaning of Qurünan it is explained. This study is qualitative study by using text analysis method in Al-Quran with the help of Corpus Al-Qurán, Al-Mu'jam Al-Mufahras Li Alfaz Al-Quran and Mu'jam Al-Waseet Dictionary Fourth Edition. The search results in the Corpus of Al-
\end{abstract}


Quran show that a total of 36 verses related to $َ \dot{\jmath}$ w were identified while the search results in Mu'jam Al-Mufahras Li Alfaz Al-Quran also had 40 verses from the keyword $\dot{j} \dot{j}$. As for the dictionary Mu'jam Al-Waseet Fourth Edition also interprets 20 different meanings of words. These findings conclude that semantic relationships are suitable to be used as a method for systematic textual data collection to avoid data dropout and ensure that the data collected covers the field of study.

Keywords: Al-Qur'an, Qurūnan, Semantic, Text Analysis

\section{Pengenalan}

Al-Quran adalah kitab suci bagi umat Islam. Al-Quran adalah teks Ilahi yang mewakili bentuk bahasa Arab klasik yang paling murni, suci dan sahih. Al-Quran di dalamnya juga terdapat banyak ilmu pengetahuan yang tersembunyi. Semua itu terkandung dalam Al-Quran yang terdapat pada ayat-ayat. Al-Quran mengandungi 114 surat yang panjangnya tidak sama. Ayat-ayat Al-Quran berjumlah 6,660 dan kata-kata dalam Al-Quran pula berjumlah 77,639. Sebagai umat Islam, kita diwajibkan mempelajari dan beriman kepada Al-Quran kerana Al-Quran dapat dijadikan sebagai pedoman manusia terutama umat terkemudian dalam menjalani kehidupan supaya memperoleh kebahagiaan di dunia dan akhirat. Perintah untuk beriman kepada Al-Quran, seperti dalam firman Allah SWT dalam Surah Al-An 'Am ayat 155:

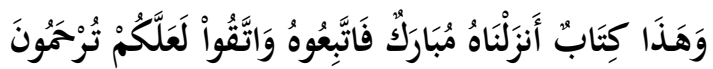

Maksudnya: "Dan ini sebuah Kitab (Al-Quran) yang Kami turunkan, yang ada berkatnya (banyak manfaatnya). Oleh itu, hendaklah kamu menurutnya dan bertakwalah (kepada Allah), mudah-mudahan kamu beroleh rahmat”. (Q.S. Al-An 'Am:155)

Selain itu, kita juga disarankan untuk memahami makna setiap ayat dalam Al-Quran. Untuk memahami makna setiap ayat-ayat dalam Al-Quran, pengetahuan mendalam tentang linguistik Arab sangat penting. Linguistik adalah kajian bahasa sebagai sistem komunikasi manusia. Terdapat beberapa cabang linguistik, antaranya adalah Semantik yang berkaitan mengenai makna dalam bahasa. Menurut Hurford (2007), semantik adalah kajian makna dalam bahasa, sedangkan hubungan leksikal menggambarkan hubungan antara makna perkataan.

\section{Perkataan Qurūnan ( قُرُونًا) dalam Al-Quran}

Perkataan "qurūnan" yang dibincangkan dalam kajian ini merujuk kepada perkataan qof ra' na (قَ $َ$ (َ) yang dalam bahasa Arabnya bermaksud "menghubungkan, menyambung, menggabungkan, menggandingkan, merangkaikan". Adapun yang mengatakan kata "quruna" ini adalah mirip dari sisi pembunyiaannya (fon) dengan kata "corona" covid-19 yang sedang melanda dunia termasuk negara Malaysia pada ketika ini. Selain daripada perkataan "qurūnan" ini ada beberapa perkataan lain yang mempunyai stuktur kata yang hampir sama dalam Al-Quran iaitu perkataan "qurnan", "muqarranīna", "qurnin" dan beberapa lagi yang lain. Walaupun perkataan-perkataan ini berasal daripada kata dasar

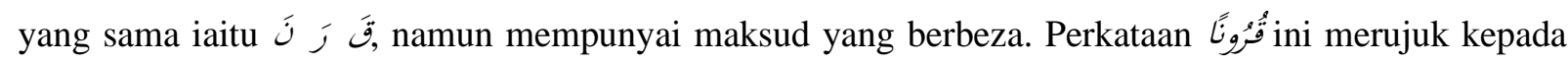

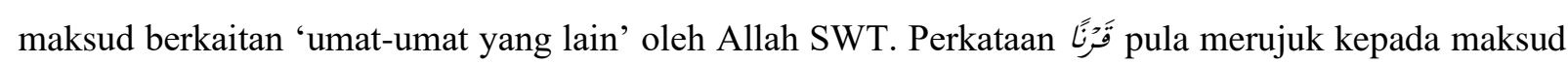
'sesudah mereka, umat yang lain' dalam Al-Quran. Manakala perkataan oَ oُ pula merujuk kepada '(orang-orang yang berdosa) pada ketika itu diberkas'.

Di dalam Al-Quran, beberapa perkataan yang mempunyai persamaan dari segi struktur kata seperti perkataan $ن$ ini. Namun begitu, setiap perkataan itu mempunyai maksud yang berbeza mengikut perkataan, konteks penggunaan ayat dan kepadanan makna ayat-ayat Al-Quran tersebut. Maka, untuk 
memahami konteks makna sebenar perkataan-perkataan dalam Al-Quran itu sangat penting agar dapat memberikan makna yang tepat, sahih dan sesuai dengan maksud dan tujuan agar Al-Quran dapat difahami oleh manusia sebaiknya. Akar kata قُرُْونًا ini adalah tersusun dari kata dasar dengan suku kata

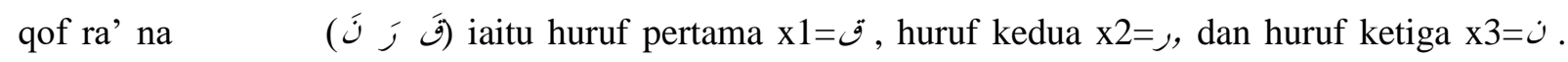
Perkataan قُرُونَ yang menggambarkan generasi atau umat-umat yang lain itu, Allah SWT rujuk kepada kaum Nabi Saleh 'Alaihissalam, kaum Nabi Luth 'Alaihissalam dan kaum Nabi Syu'aib 'Alaihissalam dalam Al-Quran disebut tiga kali sahaja iaitu dalam Surah Al-Mukminun, Al-Furqan dan Al-Qisas.

Surah Al-Mukminun mempunyai 118 Ayat dan Surah ke-23 dalam Al-Quran dan diturunkan di Mekah. Dalam Surah Al-Mukminun ini, perkataan kata dasar qof ra' na (ََ) ini ada disebut sebanyak dua

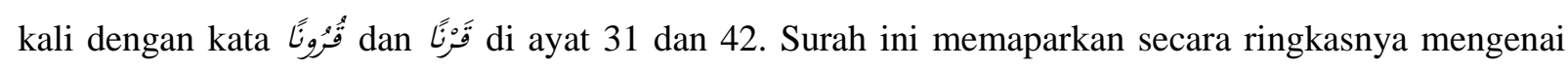
penciptaan manusia itu sendiri dengan dilengkapi dengan kelengkapan untuk mendapat rahmat dan dimasukkan ke syurga. Bahkan Nabi Adam A.S dan seluruh ruh berasal dari syurga. Juga memaparkan kisah pembinaan generasi atau umat-umat yang lain itu dan konflik pertembungan antara Nabi dengan tradisi taklid buta yang menyembah berhala. Taklid yang diwariskan secara paksa ini turun temurun sehingga para Nabi ditentang hanya kerana melawan arus yang telah dibina oleh datuk moyang mereka terdahulu. Penciptaan manusia adalah bukti kebenaran Al-Quran kerana lebih 1400 tahun dahulu tiada sebarang teknologi canggih yang mengesahkan apa yang disebut oleh Rasulullah SAW mengenai apa yang berlaku dalam kandungan atau rahim ibu.

Seterusnya manusia dikaitkan pula dengan air kerana manusia (umat) berasal dari air (air mani). Kesemua kisah-kisah Nabi dalam Surah ini ada kaitan dengan air, sebagai contoh kisah Nabi Nuh dan bahteranya. Di awal surah ini memaparkan mengenai syurga yang mengalir air di bawahnya dan penciptaan manusia bermula dengan air. Dalam ayat ke-31; menceritakan bagaimana perjuangan Nabi Hud A.S yang diutuskan Allah SWT kepada kaumnya yang mendustakan Hari Akhirat sehingga mendapat azab Allah SWT.

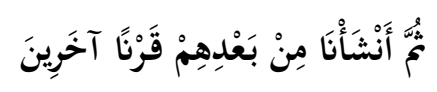

Yang bermaksud: “Kemudian Kami ciptakan sesudah mereka, umat yang lain” (23:31).

Jika dilihat ayat seterusnya, 32; yang berfirman: "Lalu, Kami mengutus kepada mereka seorang Rasul dari kalangan mereka (dengan berfirman melalui Rasul itu): "Sembahlah kamu akan Allah, (sebenarnya) tiada Tuhan bagi kamu selain daripadaNya. Oleh itu, tidakkah kamu mahu bertaqwa kepadaNya?". Dalam ayat ini, dimaksudkan Allah SWT mengutus ke dalam mereka seorang Rasul dan bukanlah kepada mereka.

Manakala dalam ayat ke-42 pula mengisahkan Rasul-Rasul seterusnya (selepas Nabi Hud A.S) yang menghadapi tentangan yang sama dari kaum yang juga mendustakan hari Akhirat lalu mereka diazab Allah SWT. Firman Allah SWT dalam Surah Al-Mukminun ayat ke-42 pula:

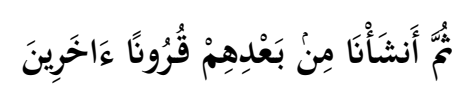

Maksudnya: “Kemudian Kami ciptakan, sesudah mereka, umat-umat yang lain” (23:42)

Dapat dijelaskan di sini mengenai perjalanan atau destinasi hidup manusia (umat) dan memaparkan peringkat-peringkat perjalanan hidup mereka yang telah dan akan terus dilalui atau ditempuhi. Surah ini juga memaparkan terlebih dahulu destinasi yang seharusnya umat manusia tujui iaitu syurga dan bekalan amalan apakah yang perlu dibawa manusia (umat) ke alam sana. Di tengah-tengah kandungan ayat dalam surah ini pula memaparkan kisah perjalanan sejarah hidup manusia (umat) dari zaman Nabi Nuh A.S. hinggalah zaman Nabi Muhammad SAW (Rasulullah SAW) yang mendustakan khabarkhabar Hari Akhirat. 
Seterusnya perkataan فُرُونًا Dalam Surah Al-Furqan, Allah SWT berfirman dalam ayat ke-38:

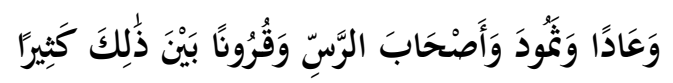

Maksudnya: "Dan (telah Kami binasakan) kaum 'Aad dan Thamud dan penduduk Rass serta ramai (lagi) generasi di antara (kaum-kaum) itu” (25:38)

Mengambil iktibar dari kisah-kisah umat terdahulu, disebutkannya kisah-kisah para nabi sebagai hiburan bagi Nabi Muhammad SAW terhadap gangguan yang menimpa Baginda dari kaumnya. Kaum 'Aad dan Thamud dan penduduk Rass serta banyak lagi generasi di antara kaum-kaum itu telah Allah hancurkan sehancur-hancurnya. Kisah kaum (umat) Aad dan Thamud adalah dua bangsa yang disebutkan beberapa kali dalam Al-Quran. Mereka sering dibincangkan ketika Allah mengarahkan perhatian kita kepada orang-orang yang tidak taat kepada-Nya dan akibatnya dihukum. Kaum Thamud dan Aad tinggal di lembah bernama al-Hajr yang kini disebut Madain Saleh di Arab Saudi. Mereka menjalani kehidupan mewah dengan nikmat makanan, buah-buahan, daging dan susu. Tetapi, suatu hari bahagian yang tragis ketika mereka melupakan Allah SWT yang telah memberkati mereka dengan semua kurniaan itu. Mereka kehilangan semua yang ada di dunia dan tidak bersyukur kepada Allah yang mengurniakan keberkatan kepada mereka.

Dalam tafsir Ibnu Abbas; perkataan wa qurūnam baina dzālika katsīrā memberi maksud; (dan banyak lagi generasi di antara kaum-kaum itu), Yakni umat-umat yang jumlahnya berkali lipat daripada mereka yang telah disebutkan, semuanya telah Kami binasakan. Adapun mengenai penduduk Rass, menurut Ibnu Juraij, dari tafsir Ibnu Abbas disebutkan bahawa mereka adalah penduduk suatu kota dari kalangan kaum Thamud. Menurut Ibnu Juraij, Ikrimah pernah mengatakan bahawa penduduk Rass bertempat tinggal di Falj, mereka adalah penduduk Yasin. Manakala Qatadah mengatakan bahawa Falj termasuk salah satu kota yang terletak di Yamamah.

Dalam Surah Al-Furqan ini boleh diambil iktibar dengan penunjukkan kebenaran agung, bahawa Allah SWT telah menciptakan umat manusia untuk memenuhi suatu tujuan sangat luhur dan mulia, dan barang siapa gagal memenuhi tujuan itu, ia akan kehilangan rahmat dan kurniaanNya.

Lagi Firman Allah SWT dalam Surah Al-Qisas ayat ke-45:

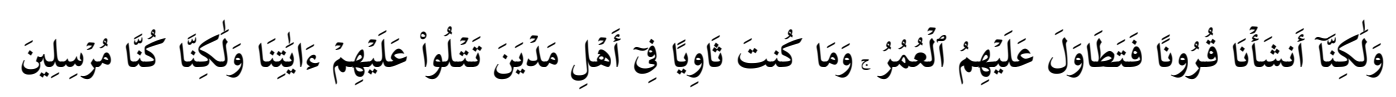

Maksudnya: ""Akan tetapi, Kami telah menciptakan beberapa umat dan telah berlalu atas mereka masa yang panjang. Engkau (Nabi Muhammad) tidak pula tinggal bersama-sama penduduk Madyan, (sehingga dapat) membacakan ayat-ayat Kami kepada mereka. Akan tetapi, Kamilah pengutus (para rasul)" (28:45)

Dalam ayat di atas ini, diterangkan bahawa Allah SWT telah menciptakan generasi demi generasi sejak zaman Nabi Musa A.S hingga kepada zaman Nabi Muhammad S.A.W dalam waktu yang panjang dan merupakan masa kekosongan, sehingga ilmu pengetahuan mereka berkurang, akhlak mereka menurun dan sehinggalah menjurus kepada kehancuran dan kemerosotan moral. Pada waktu itu, perlunya diutus seorang Rasul untuk membimbing dan memberi petunjuk kepada mereka menuju ke jalan yang benar. Maka, Allah SWT mengutuskan Nabi Muhammad SAW dan Baginda diberitahu oleh Allah SWT keadaan dan peristiwa nabi-nabi terdahulu, begitu juga keadaan dan kisah Nabi Musa A.S. Allah SWT juga menerangkan pada ayat ini bahawa Nabi Muhammad SAW tidak tinggal bersama penduduk Madyan untuk menanyakan dan mempelajari kisah Nabi Musa dan orang-orang yang menyaksikan kisah itu. Adapun semua itu diketahui sendiri oleh Nabi Muhammad SAW melalui perantaraan wahyu yang diturunkan Allah SAW kepada Baginda Rasulullah SAW.

Ketiga-tiga perkataan umat Nabi pada zaman terdahulu itu tidak patuh atau ingkar terhadap perintah Allah SWT dan tidak 
meneruskan kepatuhan kepadaNya, maka Allah SWT telah menghantar tentera-tentera (junjullah) dalam pelbagai cara dan bentuk untuk menyerang dan menegur umat-umat yang ingkar.

Sebilangan di antara mereka mendefinisikan qarn bahawa satu kurun sama dengan seratus dua puluh tahun. Menurut pendapat yang lain seratus tahun, menurut pendapat yang lain lapan puluh tahun, ada pula yang mengatakan empat puluh tahun, dan banyak lagi pendapat lainnya yang berbeza. Namun menurut pendapat yang kuat, apa yang dimaksudkan dengan qarn adalah umat yang ada di suatu kurun waktu (suatu zaman). Apabila mereka semuanya telah tiada, lalu diganti oleh generasi yang baru, maka generasi itu dinamakan qarn yang lain (generasi yang lain). Seperti yang disebutkan di dalam Hadis Nabi melalui salah satu sabda Nabi Muhammad SAW melalui sabdanya:

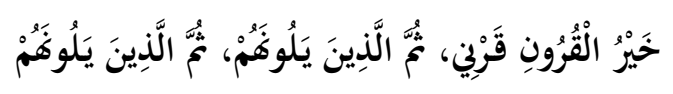

Yang bermaksud: "Sebaik-baik generasi adalah generasiku, kemudian orang-orang (generasi) yang sesudahnya, kemudian orang-orang (generasi) yang sesudahnya lagi”. Riwayat al-Bukhari (3651)

\section{Kajian Literatur}

Mengkaji literatur yang berkaitan adalah penting untuk membentuk hujah yang padu dan koheren dalam mencari jurang teori, dasar dan metodologi yang dikaji. Kajian Literatur bagi menerangkan katakata Al-Quran, menafsirkan maknanya ke dalam bahasa Arab dan bahasa lain telah banyak dibuat, walau bagaimanapun literatur mengenai secara khusus berkaitan dengan analisis makna Semantik perkataan Qurūnan dalam Al-Quran secara khususnya masih belum ditemui.

Ini bermakna kajian ini merupakan satu kajian baru yang diperlukan agar orang ramai dapat memahami kandungan Al-Quran dengan lebih baik. Ini adalah sangat penting dalam meningkatkan pemahaman Al-Quran secara keseluruhan di kalangan masyarakat di Malaysia khususnya dan dunia Muslim yang lestari. Namun begitu, beberapa kajian telah dibuat dalam bidang yang hampir sama mengenai dengan analisis makna Semantik perkataan Qurūnan dalam Al-Quran.

\section{Corona, Bahasa Arab dan Literasi Keislaman}

Kajian yang ada dilakukan adalah berkaitan dengan Corona, Bahasa Arab dan Literasi Keislaman (Asep Supianudin, Mawardi, Irfan Adriadi \& Dina Marliana, 2020) yang menyentuh isu corona dan bahasa Arab. Kajian khusus berkaitan perkataan corona dalam bahasa Arab dan literasi keislaman ini dapat dilihat dalam penulisan artikel di Bandung, Indonesia. Artikel ini merupakan hanya kandungan mengenai hasil penelitian sederhana sebagai reaksi akademik atas kejadian pandemik virus corona di seluruh dunia di awal tahun 2020.

Penulisan ini memberi fokus kepada dua perkara iaitu hubungan corona dengan bahasa Arab dan hubungan corona dengan literasi keislaman Indonesia. Penghasilan kajian ini dilakukan penelitian kecil terhadap fakta-fakta yang muncul berkenaan dengan pandemik corona ini. Penulis kemudiannya menggunakan fakta-fakta ini sebagai sumber data iaitu teks yang merupakan bahasa Arab dan teks lain yang bukan merupakan bahasa Arab akan tetapi berisikan kandungan keislaman berkenaan dengan pandemik corona. Hasil kajian ini, menyatakan bahawa sebagai sebuah istilah kata "corona" diserap ke dalam bahasa Arab dengan istilah كورونا

Adapun dalam kajian ini penulis mengulas mengenai perkataan corona dalam bahasa Arab mempunyai kemiripan dengan beberapa kata bahasa Arab. Di antaranya ada satu kata yang mirip dari sisi pembunyiannya iaitu "qorona" ( قرن ). Dalam bahasa Arab, kata ق ن ن ini bermakna "menghubungkan, memasangkan, menggabungkan, menggandengkan, merangkaikan”. Penulis mengulas lagi, jika kata ini dianggap sebagai bahasa Arabnya dari virus corona tentu merupakan hal yang tidak tepat. Menurut 
Halimi Zuhdy, istilah Corona yang dipakai dalam bahasa Arab (yang banyak digunakan) iaitu كورونا, (Zuhdy, 2020).

\section{Analisis Leksikografi dan Semantik Terhadap Perkataan Al-Kafur}

Keunikan Bahasa Arab Semantik menjadikan gabungan Analisis Leksikografi dan Semantik lebih signifikan untuk menganalisis makna perkataan-perkataan dalam Al-Quran. Kajian ini (Ramli, Atoh, Zakaria, \& Abd Rahman, 2018) mengenai Analisis Leksikografi dan Semantik terhadap perkataan alKafur yang dibincangkan merujuk kepada perkataan al-Kafur yang bermaksud tumbuh-tumbuhan. Selain perkataan al-Kafur ini, terdapat perkataan lain yang mempunyai struktur yang hampir sama dalam Al-Quran iaitu perkataan s ف ف Salaupun kedua-dua perkataan ini berasal dari kata dasar

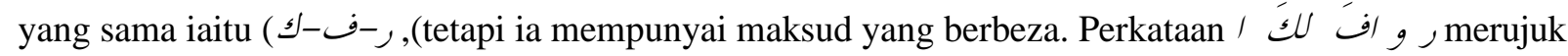
kepada maksud berkaitan dengan nikmat yang dikurniakan oleh Allah S.W.T sama ada jenis tumbuhtumbuhan, sifat tumbuh-tumbuhan, mata air atau pun nama anak sungai yang terdapat di dalam syurga. Manakala perkataan 3 i pula merujuk kepada maksud menutup. Orang yang tidak beriman dikenali sebagai orang kafir kerana iman mereka tertutup (Ibn Manzur, 1996).

Perbincangan secara khusus berkaitan dengan analisis leksikografi perkataan al-Kafur dalam Al-Quran tidak banyak dilakukan oleh para pengkaji sebelum ini. Kebanyakan kajian yang dilakukan adalah berkaitan dengan tumbuh-tumbuhan dalam Al-Quran yang menyentuh bidang saintifik tumbuhtumbuhan, tumbuh-tumbuhan dan sains pertanian, tumbuh-tumbuhan dan sains perubatan, fiqh pertanian dan gaya bahasa dalam Al-Quran. Kajian awal khusus berkaitan dengan dunia tumbuhtumbuhan dalam kalangan masyarakat Arab dapat dilihat dalam buku bertajuk Kitab al-Nabat oleh Abu Hanifat yang diterbitkan pada tahun 1974. Buku ini merupakan hanya kandungan dua bab dari naskah manuskrip asal. Manuskrip lengkap naskah ini berjumlah enam bab telah hilang dari tamadun peradaban Arab. Naskah yang tinggal hanya bab tiga dan bab lima yang masih tersimpan di Pusat Manuskrip Universiti Istanbul Turki ('Abd al-Qadir, 1997).

Dapatan kajian diperolehi pada peringkat awal melalui teks yang dianalisis melalui analisis isi kandungan dalam bidang tafsir Al-Quran, leksikografi Arab, Ulum Hadith, syair Arab, sains pertanian dan sains perubatan. Pada peringkat kedua, analisis perbandingan pula dilakukan antara data-data yang diperolehi dari tafsir-tafsir Al-Quran, leksikografi Arab dan Ulum Hadith dengan data dari syair Arab, sains pertanian dan sains perubatan. Analisis perbandingan antara maksud yang diberikan oleh ahli leksikon Arab dan ahli tafsir dapat memberi rumusan berkaitan dengan maksud perkataan al-Kafur seperti yang digambarkan oleh Al-Quran.

\section{Metod Kajian}

Menurut (Idid, 1992), metodologi yang sesuai digunakan dalam bidang sains sosial dan kemanusiaan ialah kaedah analisis wacana (discourse analysis). Kajian yang berkaitan dengan bahasa dan linguistik ini merupakan cabang disiplin ilmu dalam bidang sains sosial. Kajian yang dilakukan penting bagi menjadi panduan kepada pengkaji untuk mengumpul dan menganalisis data serta melakukan analisis terhadap penyelidikan yang dijalankan. Bagi kajian menganalisis makna Semantik perkataan Qurūnan dalam Al-Quran ini bersifat kualitatif, di mana kaedah analisis teks (text analysis) digunakan melalui langkah-langkah berikut:

(1) Mengenal pasti asal dan kaitan perkataan Arab "qurūnan" dalam Al-Quran.

(2) Menganalisis kata-kata "qurūnan" dalam Al-Quran.

(3) Menganalisis semantik perkataan yang mempunyai akar yang sama tetapi dalam bentuk dan maksud yang berbeza dalam beberapa ayat menggunakan paltform 
Korpus Quran, Al-Mu'jam Al-Mufahras Li Alfaz Al-Quran dan Kamus Mu'jam Al-Waseet Edisi Keempat.

Pendekatan kualitatif ini menjawab persoalan bagaimana dan kenapa sesebuah fenomena itu berlaku. Kajian kualitatif juga merupakan suatu kaedah untuk menerokai dan memahami individu atau kumpulan yang terlibat dengan sesuatu masalah atau fenomena manusia dan masyarakat.

\section{Hasil dan Perbincangan Kajian}

\section{Analisis Semantik dan Aplikasinya dalam memahami Teks Al-Quran}

Semantik adalah bahagian dari struktur bahasa yang berhubungan dengan makna ungkapan dan dengan struktur makna suatu pembicaraan. Definisi lain semantik adalah ilmu yang berkaitan dengan makna atau erti kata. Makna adalah maksud pembicaraan, pengaruh satuan bahasa dalam pemahaman persepsi, serta perilaku manusia atau kelompok. Pendapat lain dikemukakan oleh Chaer yang menyatakan bahawa dalam semantik yang dibicarakan adalah hubungan antara kata dengan konsep atau makna dari kata tersebut, serta benda atau hal-hal yang dirujuk oleh makna itu yang berada diluar bahasa. Makna dari sebuah kata, ungkapan atau wacana ditentukan oleh konteks yang ada.

Semantik secara etimologi perkataan semantik diserap dari bahasa Inggeris, 'semantics'. Dalam beberapa literatur bahasa Arab, semantik disebut dengan pelbagai; iaitu "bahkan disebut " الداللة علم ' " “. Secara terminologinya pula, semantik adalah sebahagian daripada kajian linguistik yang menjadikan makna sebagai objek kajian. Makna adalah makna sesuatu perkataan telah berubah dari makna dasarnya. Manakala makna asas adalah apa yang disebut makna. Tujuan mempelajari linguistik dapat memberikan faedah bagi setiap orang yang berjuang dalam dunia bahasa. Apa yang dimaksudkan dengan makna dan perbezaan dengan makna perlu dijelaskan. Terdapat dua jenis makna, iaitu makna leksikal dan makna tatabahasa. Hubungan makna juga boleh disebut corak struktur leksikal. Dimana makna kata-kata itu berubah dalam bentuk pola yang terpisah, iaitu pola tautan semantik. Tautan semantik hubungan antara makna adalah seperti Sinonim, Polisemi, Homonim, Antonim dan Hiponim.

Berdasarkan beberapa pendapat di atas dapat disimpulkan bahawa semantik adalah ilmu yang menelaah lambang-lambang atau tanda-tanda yang menyatakan makna, hubungan makna yang satu dengan yang lain, serta hubungan antara kata dengan konsep atau makna dari kata tersebut.

\section{a. Pengertian Makna}

Makna kata merupakan bidang kajian yang dibahaskan dalam ilmu semantik. Semantik berkedudukan sebagai salah satu cabang ilmu linguistik yang mempelajari tentang makna suatu kata dalam bahasa.

\section{b. Jenis-jenis Makna}

Jenis makna dapat dibezakan berdasarkan beberapa kriteria dan dari sudut pandang. Berdasarkan jenis semantiknya dapat dibezakan antara makna leksikal, makna gramatikal dan kontekstual. Berdasarkan ada atau tidak referen pada sebuah kata dapat dibezakan adanya makna referensial dan nonreferensial. Berdasarkan ada tidaknya nilai rasa pada sebuah kata dapat dibezakan adanya makna konotatif dan denotatif. Berdasarkan ketepatan maknanya dapat dibezakan adanya makna istilah dan makna-makna kata.

Selain itu, semantik juga merupakan bidang keilmuan linguistik yang membahaskan tentang makna ungkapan bahasa atau makna dari hubungan antara kata yang membentuk frasa, klausa, kalimat mahupun wacana. Semantik Maksud atau Makna merupakan salah satu daripada jenis-jenis Semantik yang berkaitan dengan penggunaan bentuk-bentuk gaya seperti Metafora, Ironi dan Litotes dan lain- 
DOI: https://doi.org/10.47405/mjssh.v6i9.1009

lainnya. Verhaar mendefinisikan semantik maksud atau makna ini sama dengan istilah semantik pragmatik yang dikemukakan oleh pakar-pakar lain dan biasanya dimaksudkan dengan bidang pengajian semantik yang mempelajari makna sebutan yang sesuai dengan konteks situasinya. Mengambil contoh metafora kitab suci Al-Quran dan Hadis Nabi merupakan teks yang sering menggunakan ayat sindiran (hyperbolic satire) untuk menyampaikan maksud dan tujuan yang ingin disampaikan.

\section{Kata Qurūnan dalam Al-Quran}

Kata qurūnan dalam Al-Quran dengan pelbagai variasinya disebutkan sebanyak 36 kali berkaitan قَ dalam Korpus Al-Quran manakala hasil carian dalam Mu'jam Al-Mufahras Li Alfaz Al-Quran pula

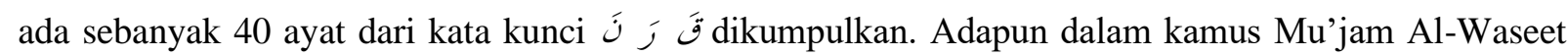
Edisi Keempat pula menafsirkan 20 makna perkataan yang berbeza boleh dilihat dalam Jadual 1, 2 dan 3 berikut:

i. Korpus Al-Quran; Kata akar tiga huruf qaf ra nun $(\dot{ })$ ( ) terdapat 36 kali dalam Al-Quran, dalam lima bentuk yang berasal:
a. 23 kali sebagai kata nama qarn (قرن)
b. lapan kali sebagai kata nama qarīn (فَرَين)

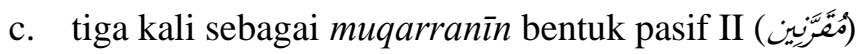
d. sekali sebagai muq'rinīn aktif bentuk IV (مُقعبينين)

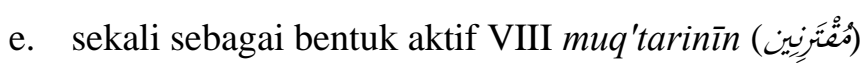

Jadual 1: Kata qurūnan hasil carian dalam Korpus Al-Quran

\begin{tabular}{|c|c|c|c|c|c|c|c|c|c|c|c|}
\hline No. & $\begin{array}{c}\text { Bentuk } \\
\text { kata }\end{array}$ & $\begin{array}{l}\text { Nama } \\
\text { Surah }\end{array}$ & $\begin{array}{c}\text { Nombor } \\
\text { Ayat }\end{array}$ & Jumlah & Sejarah & No. & $\begin{array}{c}\text { Bentuk } \\
\text { kata }\end{array}$ & $\begin{array}{l}\text { Nama } \\
\text { Surah }\end{array}$ & $\begin{array}{c}\text { Nombor } \\
\text { Ayat }\end{array}$ & Jumlah & Sejarah \\
\hline 1. & قَرْنٍ & Al-An'am & 6 & 1 & Makiyyah & 19. & الْقُعُونِ & $\begin{array}{c}\text { As- } \\
\text { Sajdah }\end{array}$ & 26 & 1 & Makiyyah \\
\hline 2. & قَرَنًا & Al-An’am & 6 & 1 & Makiyyah & 20. & الُْقُرُونِ & Yaseen & 31 & 1 & Makiyyah \\
\hline 3. & الُُْعُونَ & Yunus & 13 & 1 & Makiyyah & 21. & هَرْنِ & Sad & 3 & 1 & Makiyyah \\
\hline 4. & الْقُعُونِ & Hud & 116 & 1 & Makiyyah & 22. & الْقُرُونُ & Al-Ahqaf & 17 & 1 & Makiyyah \\
\hline 5. & الْقُعُونِ & Al-Isra' & 17 & 1 & Makiyyah & 23. & قَرَنٍْ & Qaf & 36 & 1 & Makiyyah \\
\hline 6. & الْقَرَنَنْنِ & Al-Kahf & 83 & 1 & Makiyyah & 24. & قَرِيًا & An-Nisa' & 38 & 1 & Madani \\
\hline 7. & الْقَرَنَنْنِ & Al-Kahf & 86 & 1 & Makiyyah & 25. & 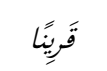 & An-Nisa' & 38 & 1 & Madani \\
\hline 8. & الْقَرْنَنْنِ & Al-Kahf & 94 & 1 & Makiyyah & 26. & & $\begin{array}{c}\text { As- } \\
\text { Saafaat }\end{array}$ & 51 & 1 & Makiyyah \\
\hline 9. & قَرْنٍ & Maryam & 74 & 1 & Makiyyah & 27. & قُرَنَاءَ & Fussilat & 25 & 1 & Makiyyah \\
\hline 10. & قَرٍْْ & Maryam & 98 & 1 & Makiyyah & 28. & قَرِيْنُ & $\begin{array}{c}\text { Az- } \\
\text { Zukhruf }\end{array}$ & 36 & 1 & Makiyyah \\
\hline 11. & الُُْعُونِ & Ta-Ha & 51 & 1 & Makiyyah & 29. & الََْْرِينُ & $\begin{array}{c}\text { Az- } \\
\text { Zukhruf }\end{array}$ & 38 & 1 & Makiyyah \\
\hline 12. & الْقُعُونِ & Ta-Ha & 128 & 1 & Makiyyah & 30. & قَرِيِنُ & Qaf & 23 & 1 & Makiyyah \\
\hline 13. & قَرْنًَا & $\begin{array}{c}\text { Al- } \\
\text { Mukminun }\end{array}$ & 31 & 1 & Makiyyah & 31. & قَرِيْنُة & Qaf & 27 & 1 & Makiyyah \\
\hline 14. & قُرُونًا & $\begin{array}{c}\text { Al- } \\
\text { Mukminun }\end{array}$ & 42 & 1 & Makiyyah & 32. & مُعَرَزبنينَ & Ibrahim & 49 & 1 & Makiyyah \\
\hline 15. & وَتُقُرُونًا & Al-Furqan & 38 & 1 & Makiyyah & 33. & & $\begin{array}{l}\text { Al- } \\
\text { Furqan }\end{array}$ & 13 & 1 & Makiyyah \\
\hline 16. & الُْقُرُونَ & Al-Qasas & 43 & 1 & Makiyyah & 34. & مُعَعَزَنينَ & $\mathrm{Sad}$ & 38 & 1 & Makiyyah \\
\hline 17. & قُرُونًا & Al-Qasas & 45 & 1 & Makiyyah & 35. & مُعْرِنِينَ & $\begin{array}{c}\text { Az- } \\
\text { Zukhruf }\end{array}$ & 13 & 1 & Makiyyah \\
\hline
\end{tabular}


Malaysian Journal of Social Sciences and Humanities (MJSSH), Volume 6, Issue 9, (page 321 - 334), 2021

DOI: https://doi.org/10.47405/mjssh.v6i9.1009

18.

\begin{tabular}{lllll} 
الْقُعُونِ & Al-Qasas & 78 & 1 & Makiyyah \\
\hline
\end{tabular}

36.

Az-
Zukhruf

53

Makiyyah

ii. Mu'jam Al-Mufahras Li Alfaz Al-Quran pula ada sebanyak 40 ayat dari kata kunci dikumpulkan dalam 13 bentuk kata seperti dalam Jadual 2 berikut:

Jadual 2: Kata qurūnan hasil carian dalam Mu'jam Al-Mufahras Li Alfaz Al-Quran

\begin{tabular}{|c|c|c|c|}
\hline Bentuk Kata & Jumlah & Nama Surah & Nombor Ayat \\
\hline \multirow[t]{5}{*}{ قَرْنِ } & 5 & Al-An'am & 6 \\
\hline & & Maryam & 74 \\
\hline & & Maryam & 98 \\
\hline & & Sad & 3 \\
\hline & & Qaf & 36 \\
\hline \multirow[t]{2}{*}{ قَرْنًَا } & 2 & Al-An'am & 6 \\
\hline & & Al-Mukminun & 31 \\
\hline \multirow[t]{3}{*}{ الُْقَرَزَيْنِ } & 3 & Al-Kahfi & 83 \\
\hline & & Al-Kahfi & 86 \\
\hline & & Al-Kahfi & 94 \\
\hline \multirow[t]{10}{*}{ الُُْعُوَنَ } & 10 & Yunus & 13 \\
\hline & & Hud & 116 \\
\hline & & Al-Isra' & 17 \\
\hline & & Тa-Ha & 51 \\
\hline & & Ta-Ha & 128 \\
\hline & & Al-Qisas & 43 \\
\hline & & Al-Qisas & 78 \\
\hline & & As-Sajdah & 26 \\
\hline & & Yaseen & 31 \\
\hline & & Al-Ahqaf & 17 \\
\hline \multirow[t]{3}{*}{ قِقُرُونًا } & 3 & Al-Mukminun & 42 \\
\hline & & Al-Furqan & 38 \\
\hline & & Al-Qisas & 45 \\
\hline \multirow[t]{3}{*}{ قَقِينِّ } & 3 & As-Saafaat & 51 \\
\hline & & Az-Zukhruf & 36 \\
\hline & & Az-Zukhruf & 38 \\
\hline قَرِينًا & 2 & An-Nisa' & 38 \\
\hline \multirow[t]{2}{*}{ 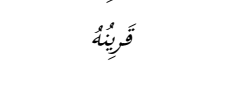 } & 2 & Qaf & 23 \\
\hline & & & 27 \\
\hline قُقُرَنَاءَ & 1 & Fussilat & 25 \\
\hline \multirow[t]{3}{*}{ 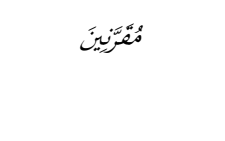 } & 3 & Ibrahim & 49 \\
\hline & & Al-Furqan & 13 \\
\hline & & $\mathrm{Sad}$ & 38 \\
\hline مُعْترِينَنَ & 1 & Az-Zukhruf & 13 \\
\hline مُعُعَرْيَنَ & 1 & Az-Zukhruf & 53 \\
\hline \multirow[t]{4}{*}{ قَارُونَّ } & 4 & Al-Qisas & 76 \\
\hline & & Al-Qisas & 79 \\
\hline & & Al-'Ankabuut & 39 \\
\hline & & Ghafir & 24 \\
\hline
\end{tabular}

iii. Kamus Mu'jam Al-Waseet Edisi Keempat pula menafsirkan 18 bentuk perkataan dasar Qurūnan yang hampir sama dengan Kamus Kontekstual Lengkap Al-Khalil boleh dilihat dalam Jadual 3 berikut: 
DOI: https://doi.org/10.47405/mjssh.v6i9.1009

Jadual 3: Analisis Perbandingan bentuk perkataan dasar Qurūnan

\begin{tabular}{|c|c|c|}
\hline $\begin{array}{c}\text { Kamus Mu'jam Al-Waseet } \\
\text { Edisi Keempat }\end{array}$ & $\begin{array}{l}\text { Kamus Kontekstual } \\
\text { Lengkap Al-Khalil }\end{array}$ & \\
\hline Bentuk Kata & Bentuk Kata & Makna \\
\hline قَرْنًَ - قَرَنَ & قَرَنَ - يَتُرُنُ - قَرْنَاً & $\begin{array}{l}\text { menghubungkan, menyambung, } \\
\text { menggandingkan, menjadikannya } \\
\text { sepasang, mengikat, } \\
\text { menghimpun. } \\
\text { bercantum, berhimpun sekali. } \\
\text { menghubungkan sesuatu, } \\
\text { menyambung. } \\
\text { melakukan haji qiran. } \\
\text { memukulnya di tepi rambut. }\end{array}$ \\
\hline قَقِنَ & قُرِنَ - يَتُرَنُ - قَرَنَا & $\begin{array}{l}\text { mempunyai hujung jambang yang } \\
\text { bertangkup, bertanduk } \\
\text { mengumpulkan, tinggi } \\
\text { banyak } \\
\text { bisul yang hampir pecah } \\
\text { kuat, mampu } \\
\text { menekan } \\
\text { bertanduk } \\
\text { menewaskan saingannya. }\end{array}$ \\
\hline أَقْرَنَ & 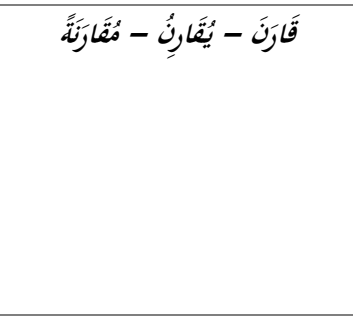 & $\begin{array}{l}\text { berkawan dengannya menemani, } \\
\text { menyertai } \\
\text { berkawan dengannya, } \\
\text { membandingkan } \\
\text { menjadikan berhubungan } \\
\text { menghubungkan sesuatu dengan } \\
\text { sesuatu, membandingkannya }\end{array}$ \\
\hline قََارَنَهُ & 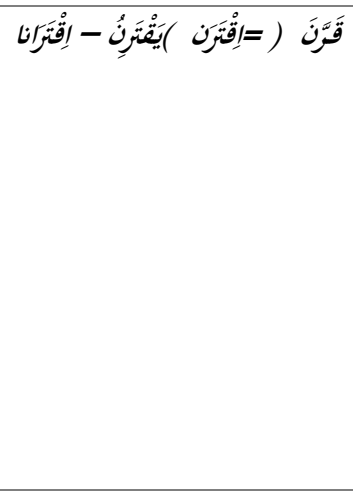 & $\begin{array}{l}\text { merantai = jin-jin syaitan yang } \\
\text { lain diletakkan dalam rantai-rantai } \\
\text { belenggu,= berhubung, bertemu, } \\
\text { bersambung } \\
\text { berhubung, bertemu, } \\
\text { berhubungan, saling berhubung = } \\
\text { telah matang, mempunyai teman } \\
\text { banyak } \\
\text { lembut = haji qiran, kahwin, tali } \\
\text { penuntun unta, tali pengikat } \\
\text { tawanan. }\end{array}$ \\
\hline ق قَََرَنَ & 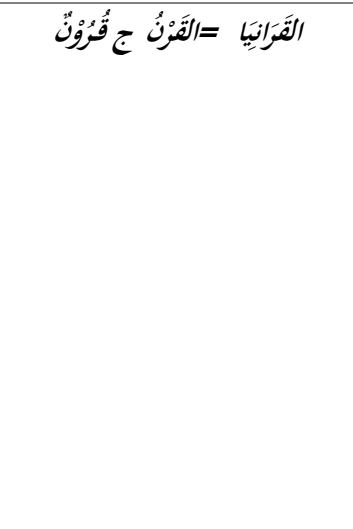 & $\begin{array}{l}\text { sejenis pokok perhiasan = seabad, } \\
\text { seratus tahun, tanduk, ubun-ubun, } \\
\text { puncak bukit, masa, generasi, } \\
\text { benteng, pusingan } \\
\text { kepala, ketua, pemimpin } \\
\text { seabad, seratus tahun } \\
\text { mata pedang } \\
\text { matahari yang mula-mula nampak } \\
\text { seperti sabit } \\
\text { puncak bukit } \\
\text { sesungut } \\
\text { satu pusingan }\end{array}$ \\
\hline القِيَانُ & القِقِنُ ج أقرنُ & yang perkasa \\
\hline القَرَانِيًا & المَتَنُ & $\begin{array}{l}\text { kotak anak panah, anak panah, } \\
\text { pedang, yang dihubungkan, tahi, }\end{array}$ \\
\hline
\end{tabular}



DOI: https://doi.org/10.47405/mjssh.v6i9.1009

\begin{tabular}{|c|c|c|}
\hline & & $\begin{array}{l}\text { unta yang digandingkan dengan } \\
\text { unta yang lain }\end{array}$ \\
\hline القِيْرنُ & العَّرَنَانُ & dua tanduk \\
\hline الََََرَنُ جَأَقْرَانُ & العَقْرئُوَة & sejenis tumbuhan \\
\hline العَّرَنَانُ & 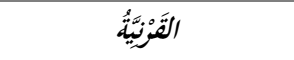 & kornea mata \\
\hline الََقْرئُوَة & العَرْزُونُ & $\begin{array}{l}\text { mutiara, yang makan dua suap } \\
\text { dua suap, jiwa } \\
\text { yang cepat berpeluh } \\
\text { yang pantas } \\
\text { yang banyak susu }\end{array}$ \\
\hline \multirow[t]{2}{*}{ القَرْيَيَّة } & العَرُؤرن & keperluan hajat \\
\hline & 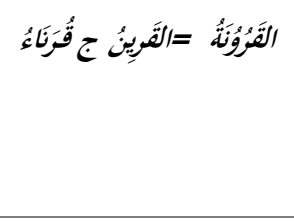 & $\begin{array}{l}\text { sejenis tumbuhan, jiwa = unta } \\
\text { yang digandingkan dengan unta } \\
\text { lain, tawanan, yang disambung, } \\
\text { suami, kawan, teman, jiwa, qarin }\end{array}$ \\
\hline 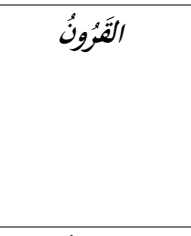 & 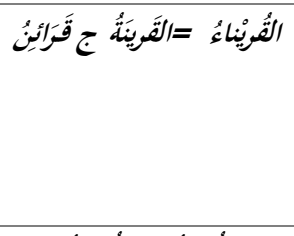 & $\begin{array}{l}\text { sejenis rumput } \\
\text { isteri, bukti, unta yang } \\
\text { digandingkan dengan unta lain, } \\
\text { jiwa, qarin, tanda, kaitan, } \\
\text { pertalian perhubungan }\end{array}$ \\
\hline 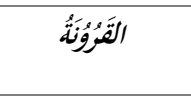 & 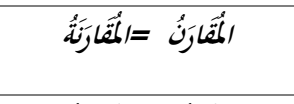 & $\begin{array}{l}\text { perbandingan } \\
\text { dibandingkan dengan yang ini }\end{array}$ \\
\hline الَقَيْنُ & 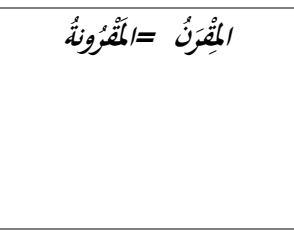 & $\begin{array}{l}\text { Kuk, kayu yang menggandingkan } \\
\text { pasangan lembu yang } \\
\text { berhubungan, } \\
\text { sejenis makanan yang dibuat } \\
\text { daripada tepung, makaroni }\end{array}$ \\
\hline \multicolumn{3}{|l|}{ 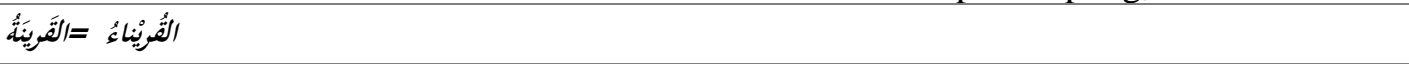 } \\
\hline 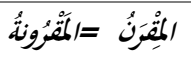 & & \\
\hline
\end{tabular}

\section{Komponen Semantik Terhadap Kata Qurūnan dalam Al-Quran}

Kandungan dalam Al-Quran banyak menceritakan tentang kisah-kisah Nabi Allah SWT. Sepertimana yang disebut dalam perbincangan di atas, komponen semantik mendefinisikan sebagai unsur-unsur perkataan yang sama membentuk makna kosa kata tertentu, di mana analisis komponen semantik pula didefinisikan sebagai huraian komponen unit-unit yang bersama-sama membentuk makna kosa kata tertentu. Kata Qurūnan dalam Al-Quran ada disebut berulang-ulang sebanyak 40 kali dalam 22 surah dengan pelbagai bentuk tatabahasanya. Kata Qurūnan jika dilihat dari penggunaan katanya dalam AlQuran dengan bentuk bahasa yang pelbagai dan menimbulkan makna perkataan yang berbeza juga, sehingga menyebabkan kecenderungan pelbagai makna Qurūnan antaranya:

a) Qurūnan dengan makna nama seorang raja yang soleh (Dhul-qarnain)

Makna ini digunakan dalam Al-Quran dengan menggunakan kata Qurūnan dalam bentuk kata:

- Isim majrur

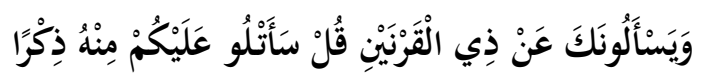

Yang bermaksud: "Dan mereka bertanya kepadamu (wahai Muhammad), mengenai Dhul-qarnain. Katakanlah: "Aku akan bacakan kepada kamu (wahyu dari Allah yang menerangkan) sedikit tentang perihalnya" (Q.S. Al-Kahfi/ 18:83). 


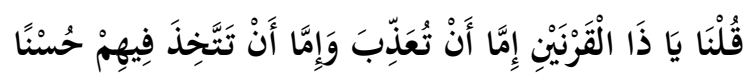

Yang bermaksud: "Kami berfirman (dengan mengilhamkan kepadanya): Wahai Dhulqarnain! Pilihlah sama ada engkau hendak menyeksa mereka atau engkau bertindak secara baik terhadap mereka". (Q.S. Al-Kahfi/ 18:86)

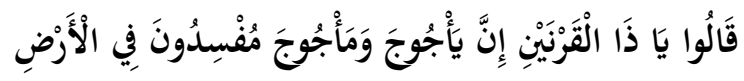

Yang bermaksud: "Mereka berkata: "wahai Dhul-qarnain, seseungguhnya Yakjuj dan Makjuj sentiasa melakukan kerosakan di bumi;" (Q.S. Al-Kahfi/ 18:94).

b) Qurūnan dengan makna umat-umatyang lain

Makna perkataan ini digunakan dalam Al-Quran dengan menggunakan kata Qurūnan dalam bentuk isim mansub, iaitu:

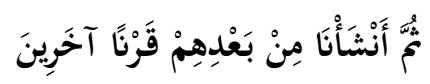

Maksudnya: "Kemudian Kami ciptakan, sesudah mereka, umat-umat yang lain" (23:42)

c) Qurūnan dengan makna teman atau qarin

Makna perkataan ini digunakan dalam Al-Quran dengan menggunakan kata Qurünan dalam bentuk isim marfu', iaitu:

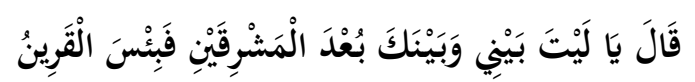

Maksdunya: "berkatalah ia (kepada Syaitannya): "Alangkah baiknya (kalau di dunia dahulu ada sekatan memisahkan) antaraku denganmu sejauh timur dengan barat! Kerana (engkau) adalah sejahat-jahat teman" (Q.S. Al-Zukhruf/ 48:38).

\section{Konsep kata Qurūnan dan sebutannya dalam Al-Quran}

Perkataan Qurūnan dan kata-kata terbitannya dalam Al-Quran ada yang bermaksud sama dan kadang kala nya berbeza makna mengikut kesesuaian struktur ayat (siyakul kalam). Berdasarkan kepada keterangan di atas jelaslah bahawa perkataan Qurūnan ini mempunyai lebih banyak persamaan makna mengikut kesesuaian bentuk perkataan atau sighahnya. Perubahan dan persamaan makna tersebut merupakan suatu yang bersifat logik untuk mencari intipati makna dan hubungannya untuk menghasilkan rangkaian makna dan konsep.

Sebagaimana yang kita tahu bahawa semantik merupakan penghuraian set kosa kata atau terma AlQuran yang bermaksud saling berhubungan membentuk pandangan dunianya. Perkataan Qurūnan dalam AL-Quran diulang sebanyak 40 kali dan dikumpulkan dalam 13 bentuk kata yang berbeza dalam pelbagai bentuk tatabahasa termasuk isim majrur, isim mansub dan isim marfu'.

Qurūnan (generasi) merupakan istilah yang digunakan berkaitan dengan umat manusia samaada yang terdahulu atau umat-umat yang lain yang didatangkan oleh Allah secara kasar atau halus. Dalam tafsir Ibnu Abbas, perkataan wa qurūnam baina dzālika katsīrā memberi maksud; (dan banyak lagi generasi di antara kaum-kaum itu), Yakni umat-umat yang jumlahnya berkali lipat daripada mereka yang telah disebutkan, semuanya telah Kami binasakan. 


\section{Kesimpulan}

Berdasarkan kepada hasil penelitian dan perbincangan yang telah dilakukan, terdapat beberapa yang dapat disimpulkan:

1) Perkataan qurūnan sering merujuk kepada kumpulan generasi atau umat-umat yang lain samada terdahulu atau yang akan datang.

2) Perkataan qurūnan dalam Al-Quran berulang sebanyak tiga kali dalam tiga Surah yang berbeza dalam pelbagai bentuk tatabahasanya. Perkataan qurūnan jika dilihat dari penggunaannya dalam Al-Quran dengan bentuk dan tatabahasanya yang bervariasi, ini mengekstrakkan makna kata yang berbeza-beza.

3) Antara makna-makna qurūnan dalam Al-Quran yang dapat dianalisis adalah:

a. qurūnan dengan makna generasi;

b. qurūnan dengan makna umat-umat yang terdahulu;

c. qurūnan dengan makna umat-umat yang lain;

d. qurūnan dengan makna umat-umat yang selepasnya umat Nabi Nuh A.S, Nabi Syuaib A.S dan Nabi Muhammad SAW.

\section{Penghargaan}

Ucapan terima kasih dan penghargaan yang tulus kepada mereka yang menyumbang dalam penyelidikan ini. Para penyelidik ingin mengucapkan terima kasih kepada Pusat Bahasa Utama Universiti Sains Islam Malaysia (USIM) untuk pengurusannya dan Prof. Madya Dr. Asma Abdul Rahman, untuk penyuntingan artikel. Penyelidikan ini disokong oleh geran penyelidikan FRGS yang bertajuk: Lexicology Latency Relational Hiperlinked - Semantic "Lexicolsem" Analisis Model Baru Untuk Komposisi Ilustrasi Al-Quran dengan Kod Kajian: FRGS/1/2020/SSI0/USIM/02/2 \& USIM/FRGS/FPBU/KPT/51220. Ribuan terima kasih kepada Kementerian Pengajian Tinggi (KPT) Malaysia yang telah menyalurkan dana bagi tujuan penyelidikan

\section{Rujukan}

A. Taá, Q. \&. (2017). Al-Quran Ontology Based on Knowledge Themes. Jounal of Fundamental and Applied Scinences 9(5S), 800-817.

Ahmed Deedat, (2008), Al-Qur'an The Miracle Of Miracles, Arhived, Wayback Machine.

Al-Quran. (n.d.).

Asep Supianudin, Mawardi, Irfan Adriadi \& Dina Marliana. (2020). CORONA, BAHASA ARAB DAN LITERASI KEISLAMAN.

Asma Abdul Rahman, (2003-2007,2012,2017,2018), Pengajian Linguistik, Bahagian Penerbitan USIM, Bandar Nilai Baru, Negeri Sembilan.

Aziyun Othman @ Omar, Mat Taib Pa \& Syakirah Rifa'in @ Mohd Rifain. (2021). Pengumpulan Data Wacana Neraka dalam Al-Quran Menggunakan Hubungan Semantik. Asia Pacific Online Journal of Arabic Studies, Volume 4 (1) , 45-57.

Dollah, D. A. (2006). Kamus Kontekstual Lengkap Al-Khalil . Kuala Lumpur: Pustaka Ilmiah Alkhalil.

Hestina, N. A. (2020). Wabah Penyakit Menular (Covid 19) dan Perumpamaan dalam Al-Quran. Jurnal Studi Al-Qur'an dan Keislaman MUMTAZ, Vol. 4, No. 02, 125-138.

I, M. (2004). Al-Mu'jam Al-Waseet. Kaherah, Mesir: Majma' Luhghah al-Arabiyyah .

Mohamed Akhiruddin Ibrahim, Hishomudin Ahmad, Robiatul Adawiyah Mohd, Muhammad Widus Sempo, \& Nur Farhana Baharuddin. (April 2018). The Word of "Basar" in Quran and Its Synonym: Comparative Study between Quran Corpus and Al-Mu'jam Al-Mufahras Li Alfaz AlQuran. IJASOS- International E-Journal of Advances in Social Sciences, Vol. IV,(Issue 10), 107113. 
Nasution, D. H. (2017). Pengantar Linguistik Bahasa Arab. S.Ag. Jawa Timur, Indonesia: Penerbit Lisan Arabi.

Ramli, S., Atoh, N., Zakaria, Z. M., \& Abd Rahman, M. (2018). Analisis Leksikografi dan Semantik Perkataan al-Kafur dalam Al-Qur'an. Journal of Language Studies, 267-283.

The Quranic Arabic Corpus (n.d). Quran Dictionary. Retrieved from https://corpus.quran.com/qurandictionary.jsp?q=qrn Accessed on 23 August 2021. 